\title{
Kisspeptin Inhibits Colorectal Cancer Cell Invasiveness by Activating PKR and PP2A
}

\author{
JEONG NAM KIM ${ }^{1}$, TAE HUN KIM², JI-HYE YOON² and SUNG-GOOK CHO ${ }^{2}$ \\ ${ }^{1}$ Department of Microbiology, College of Natural Sciences, Pusan National University, Pusan, Republic of Korea; \\ ${ }^{2}$ Department of Biotechnology, Korea National University of Transportation, Chungbuk, Republic of Korea
}

\begin{abstract}
Background/Aim: The aim of the present study was to investigate the mechanism through which kisspeptin inhibits colorectal cancer metastasis. Materials and Methods: Colorectal cancer cells were treated with kisspeptin and then subjected to assays for cell viability, migration, invasion and anchorage-independent growth. Kisspeptin receptor (KISSIR) requirement was examined by siRNA-based gene silencing followed by western blot and invasion assays. Kisspeptin regulation of $P K R$ and $P P 2 A$ was examined by treating cells with inhibitors for PKR or PP2A. Results: Kisspeptin inhibited colorectal cancer cell invasiveness without affecting cell proliferation. Kisspeptin required activation of KISSIR and resulted in activation of PKR and PP2A. PKR inhibitor blocked kisspeptin-induced $P P 2 A$ phosphorylation, while PP2A inhibitor failed to block kisspeptin-induced PKR phosphorylation. Conclusion: Kisspeptin-mediated activation of PKR-PP2A inhibited colorectal cancer cell invasiveness.
\end{abstract}

While most kisspeptin studies focus on its physiological role in the brain $(1,2)$, its function was first identified in cancer $(3,4)$. Re-introduction of KISS1 gene in metastatic breast cancer and melanoma cells repressed metastases, suggesting that a product of KISS1 gene is a metastasis suppressor (3, 4). Kisspeptin is secreted from the cells and binds to its endogenous G-protein-coupled receptor KISS1R (also named GPR54) (5-8).

KISS1 gene expression is correlated with a favorable prognosis for patients with various cancer types, thus, it is probable that kisspeptin signaling is turned off when cancer metastasizes (9-13). Kisspeptin is known to generate its own

Correspondence to: Sung-Gook Cho, Department of Biotechnology, Korea National University of Transportation, 61 University Rd. Jeungpyeong, Chungbuk 27909, Republic of Korea. Tel: +82 438205254, Fax: +82 438205272, e-mail: chosg@ut.ac.kr

Key Words: Kisspeptin, KISS1, KISS1R, PKR, PP2A, colorectal cancer. intracellular signaling through $\operatorname{KISS1R}(9,14)$. However, its signaling network that regulates phenotypes of cancer cells remains to be deciphered.

Colorectal cancer is one of the gastrointestinal cancers and its early detection improves treatment outcomes (15-17). However, colorectal cancer diagnosis is low and distant metastases are common and contribute to poor prognosis (18). Kisspeptin inhibits the invasiveness by reducing MMP9 expression in HCT-115 and HCT-119 colorectal cancer cell lines (19). Consistently, KISSI expression level is negatively correlated with MMP9 expression level in colorectal cancer tissues $(10,20)$. This relationship between kisspeptin and MMP9 was revealed in other cancer cell types $(21,22)$. Kisspeptin may reduce the expression of MMP9 by inhibiting phosphorylation of AKT in HCT-119 cells or ERK in HCT-115 cells $(10,19)$. Moreover, kisspeptin inhibits the invasiveness of LoVo colorectal cancer cells by inhibiting PKR activation (23). Nevertheless, kisspeptin-mediated intracellular signaling in colorectal cancer is still not fully understood.

The present study examined the mechanism by which kisspeptin inhibits the invasiveness of various colorectal cancer cells and may further our knowledge regarding the application of kisspeptin in treatments of colorectal cancer metastasis.

\section{Materials and Methods}

Cell culture and reagents. Colorectal cancer cell lines (CACO-2, COLO-205, HCT-116, HT-29, LoVo, LS174T, SNU0283, SNU1033, SW-620) were cultured in DMEM supplemented with $10 \%$ fetal bovine serum and $1 \%$ antibiotics. HCT-116 and HT-29 cells were obtained from ATCC while SNU-0283 and SNU-1033 cells were purchased from Seoul National Cell Line Bank. Other cell lines were obtained from Dr. Bharat Aggarwal (UT-MDA, TX, USA). PKR inhibitor $\mathrm{C} 16$ and control or KISS1R siRNA reagent system for gene silencing were purchased from Santa Cruz Biotechnology (Santa Cruz, CA, USA). PP2A inhibitor LB-100 was obtained from Selleckchem (Houston, TX, USA)., siRNA was. Anti-PKR, anti-p-PKR and anti-pPP2A antibodies were purchased from Santa Cruz Biotechnology (Santa Cruz, CA, USA). Anti-Actin, anti-AKT and anti-ERK antibodies were purchased from Cell Signaling (Danvers, MA, USA). Anti-KISS1R antibody was purchased from Abcam (Cambridge, UK). 
A
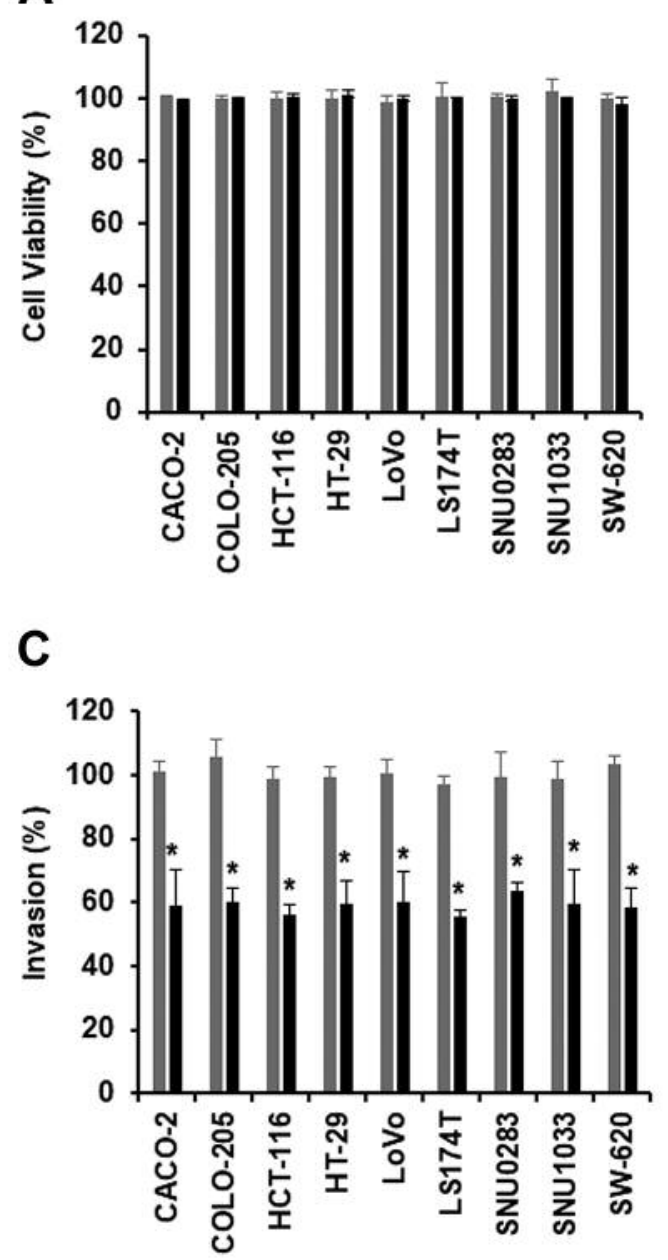

B

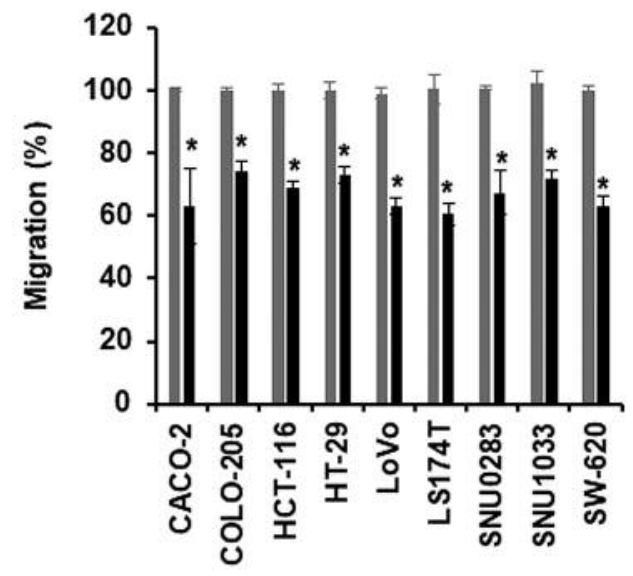

D

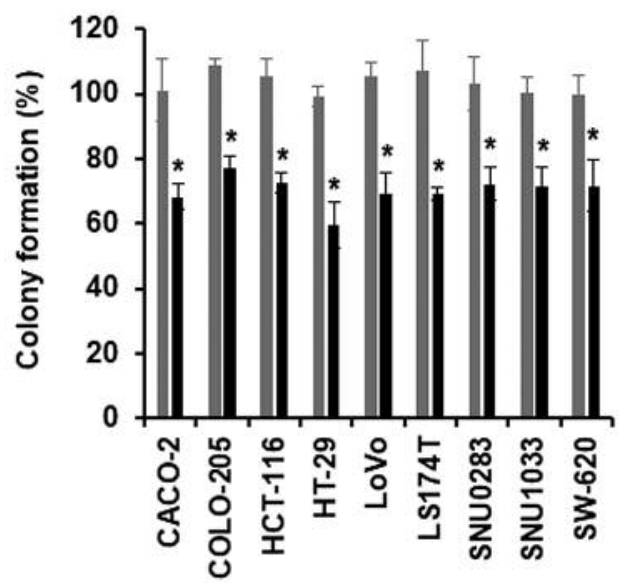

Figure 1. Kisspeptin inhibits colorectal cancer cell invasiveness. (A) Kisspeptin effect on colorectal cancer cell viability. Cells were treated with $100 \mathrm{nM}$ kisspeptin for $48 \mathrm{~h}$ and then subjected to WST assays. (B) Cells were scratched and then treated $100 \mathrm{nM}$ with kisspeptin for $24 \mathrm{~h}$. Migrated cells were counted. Experiments were performed in triplicate and repeated three times. ${ }^{*} p<0.05$. (C) Cells were cultured on the upper chamber precoated with matrigels and then treated with $100 \mathrm{nM}$ kisspeptin for $18 \mathrm{~h}$. Invaded cells were counted. ${ }^{*} p<0.05$. All data were presented as means $\pm S D$. (D) Cells were cultured in soft agars for 2 weeks and then colonies stained with crystal violet were counted. All experiments were repeated for three times. ${ }^{*} p<0.05$.

Cell viability. $3 \times 10^{4}$ colorectal cancer cells were cultured onto $96-$ well plates and then treated with kisspeptin at $100 \mathrm{nM}$ for $48 \mathrm{~h}$. Cell viability was measured by EZ-CyTox WST-based cell viability and cytotoxicity assay kit (DoGen, Seoul, Korea). Experiments were performed in triplicate.

Western blot. Protein was extracted with RIPA buffer. $30 \mu \mathrm{g}$ of protein were loaded on $10 \%$ SDS-PAGE and transferred to PVDF membranes. Anti-PKR, anti-p-PKR and anti-p-PP2A antibodies were purchased from Santa Cruz Biotechnology (Santa Cruz, CA, USA). Anti-Actin, anti-AKT and anti-ERK antibodies were purchased from Cell Signaling (Danvers, MA, USA). Anti-KISS1R antibody was purchased from Abcam (Cambridge, UK). All primary antibodies were used in a 1:1,000 dilution. Horseradish peroxidase (HRP)-linked anti-rabbit IgG and anti-mouse $\operatorname{IgG}$ antibody as secondary antibodies were used in dilution 1:20,000. Western blots were detected using LumiGLO chemiluminescent reagent and peroxidase (Cell Signaling, Danvers, WI, USA).

Migration and invasion. $3 \times 10^{5}$ cells were cultured onto 6-well plates were scratched using $200 \mu$ yellow tips and washed with PBS three times. Random cell migration was measured by counting cells migrated within the scratched regions. For invasion assays, $3 \times 10^{4}$ cells were seeded on top chambers precoated with matrigels. Top chambers were then filled with $1 \%$ serumcontaining medium, and bottom chambers were filled with $10 \%$ serum-containing medium. $18 \mathrm{~h}$ after incubation, top chambers were carefully cleared with cotton swaps, and invaded cells stained with $1 \%$ crystal violet were counted. All experiments were performed in triplicate. 


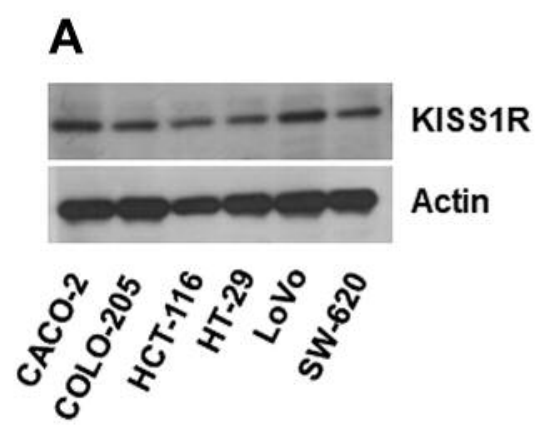

B
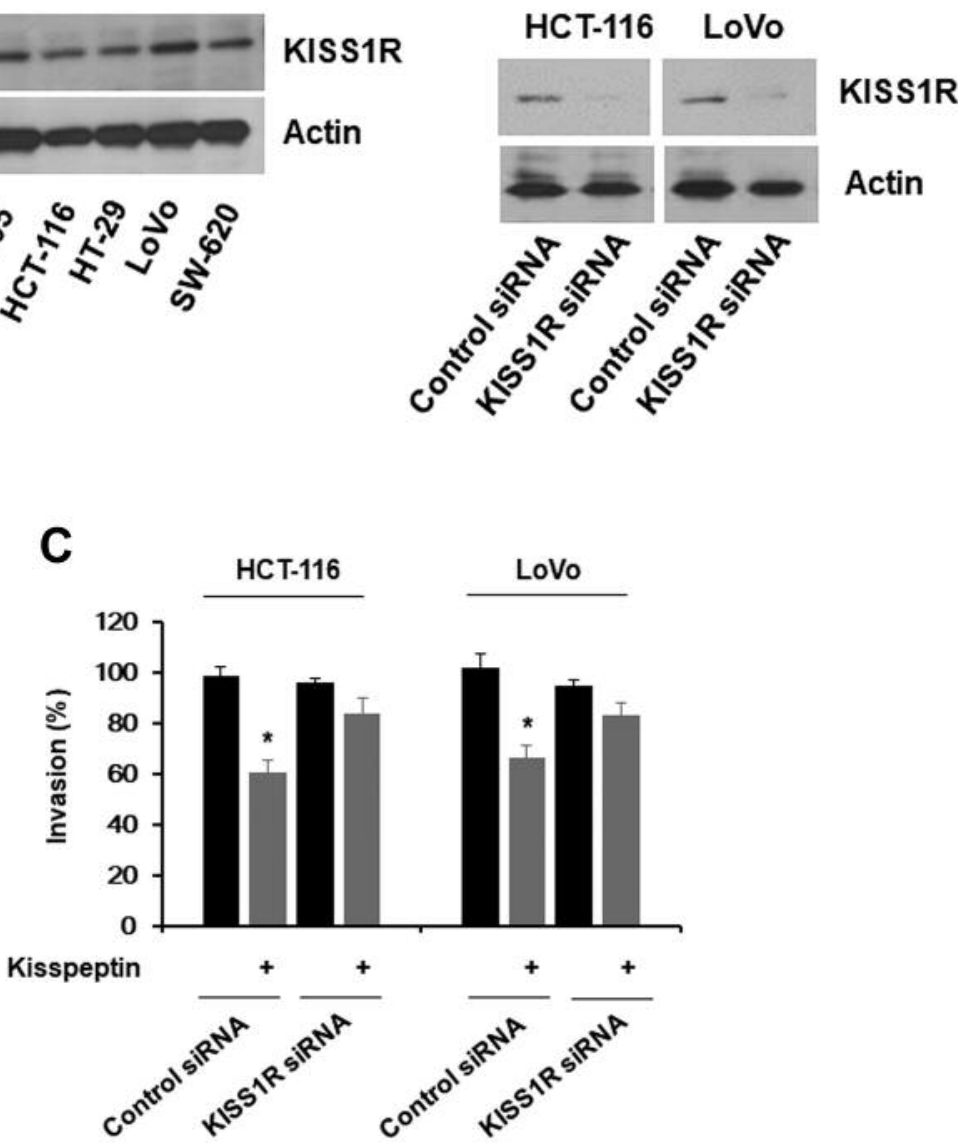

Figure 2. Kisspeptin requires KISS1R to inhibit colorectal cancer cell invasiveness. (A) KISS1R expression in different colorectal cancer cells. Actin was used as a loading control. (B) Cells were transfected with either control siRNA or KISS1R siRNA for 24 h and then subjected to western blots. (C) KISSIR was silenced for $24 \mathrm{~h}$ and then cells were subjected to invasion assays. Cells were treated with $100 \mathrm{nM}$ kisspeptin and then invasion were observed for $18 h . * p<0.05$.

Anchorage-independent growth. $3 \times 10^{4}$ cells were cultured in $0.35 \%$ soft agar for 2 weeks. Dishes were stained using 1\% Crystal Violet and macroscopically visible colonies were counted. Experiments were conducted in triplicate.

Statistics. Statistical tests were performed using Student's $t$-test or oneway ANOVA. Results were expressed as means $\pm \mathrm{SD}$ or means $\pm \mathrm{SE}$, and $p$-value less than 0.05 was considered statistically significant.

\section{Results}

Kisspeptin inhibited metastasis of colorectal cancer cells. To examine the effect of kisspeptin on colorectal cancer cell lines, different colorectal cancer cell lines (CACO-2, COLO-205, HCT-116, HT-29, LoVo, LS174T, SNU0283, SNU1033, SW620) were treated with kisspeptin at different concentrations for $48 \mathrm{~h}$ and then subjected to cell proliferation assays. Kisspeptin treatment did not affect viability of the various colorectal cancer cell lines (Figure 1A). Consistently, we failed to detect both cleaved PARP and caspase-3 (data not shown), when cells were treated with kisspeptin for $24 \mathrm{~h}$.

Next, we performed scratching assays to examine kisspeptin effect on colorectal cancer cell migration. Scratching assays indicated that treatment with kisspeptin for $24 \mathrm{~h}$ reduced colorectal cancer cell migration (Figure 1B). In addition, kisspeptin inhibited colorectal cancer cell invasiveness in two-chamber assays (Figure 1C). To confirm our findings on cell migration and invasion assays, soft agar assays were performed. Kisspeptin treatment inhibited anchorage-independent growth (Figure 1D). Collectively, our data indicate that kisspeptin inhibited metastatic abilities of colorectal cancer cells.

Kisspeptin inhibited metastasis of colorectal cancer cells via $K I S S 1 R$. Next, the requirement of KISS1R for the kisspeptin 
effects was investigated. Colorectal cancer cell lines (CACO2, COLO-205, HCT-116, HT-29, LoVo, SW-620) expressed KISS1R (Figure 2A). In the absence of KISS1R expression, following its silencing in HCT-116 and LoVo cells using KISS1R siRNAs, kisspeptin had no effect on their invasiveness (Figure 2B and 2C). These findings indicate that kisspeptin required KISS1R for the inhibition of colorectal cancer cell invasiveness.

Kisspeptin inhibited colorectal cancer cell invasiveness via $P K R$. As PKR is involved in kisspeptin inhibition of cancer cell invasiveness (23), we examined kisspeptin-mediated PKR phosphorylation in HCT-116 and LoVo colorectal cancer cells. Kisspeptin increased PKR phosphorylation in both HCT-116 and LoVo cells (Figure 3A), and KISS1R silencing with KISS1R siRNAs in HCT-116 and LoVo cells blunted kisspeptin-induced PKR phosphorylation (Figure 3B).

To confirm that kisspeptin signaling requires PKR phosphorylation in the inhibition of colorectal cancer cell invasiveness, HCT-116 or LoVo cells were pretreated with the PKR inhibitor C16 for $5 \mathrm{~min}$ and then were incubated with kisspeptin for another $12 \mathrm{~h}$. The invasion assays showed that PKR inhibition resulted in the rescue of kisspeptinblocked invasiveness (Figure 3C). Thus, our data indicate that kisspeptin involved PKR in the inhibition of colorectal cancer cell invasiveness.

Kisspeptin activation of PP2A via PKR represses the invasiveness of colorectal cancer cells. Kisspeptin inhibited phosphorylation of ERK and AKT in colorectal cancer cells $(10,19)$. Thus, to examine whether kisspeptin affects phosphorylation of ERK and AKT via PKR, HCT-116 cells were pretreated with the PKR inhibitor C16 for $5 \mathrm{~min}$ and then incubated with kisspeptin for another 15 min. C16 blocked kisspeptin-mediated PKR phosphorylation, did not affect AKT phosphorylation but increased phosphorylation of ERK, while kisspeptin alone increased phosphorylation of both PKR and AKT but not ERK phosphorylation, and C16 alone increased phosphorylation of both AKT and ERK but inhibited PKR phosphorylation (Figure 4A). Therefore, our data indicate that kisspeptin-activated PKR may inhibit phosphorylation of both AKT and ERK.

PKR is known to inhibit AKT phosphorylation via PP2A activation $(24,25)$. PP2A activation also inhibits ERK phosphorylation (26). Moreover, PP2A activity is inversely correlated with colorectal cancer progression $(27,28)$. Therefore, to examine the role of PP2A, its inhibitor LB-100 was employed. PP2A inhibitor did not affect kisspeptinmediated phosphorylation of PKR, while it increased phosphorylation of AKT and ERK (Figure 4B). Furthermore, PP2A inhibition rescued kisspeptin effect on the invasiveness of both HCT-116 and LoVo cells (Figure 4C). When HCT116 cells were pretreated with either PKR or PP2A inhibitor
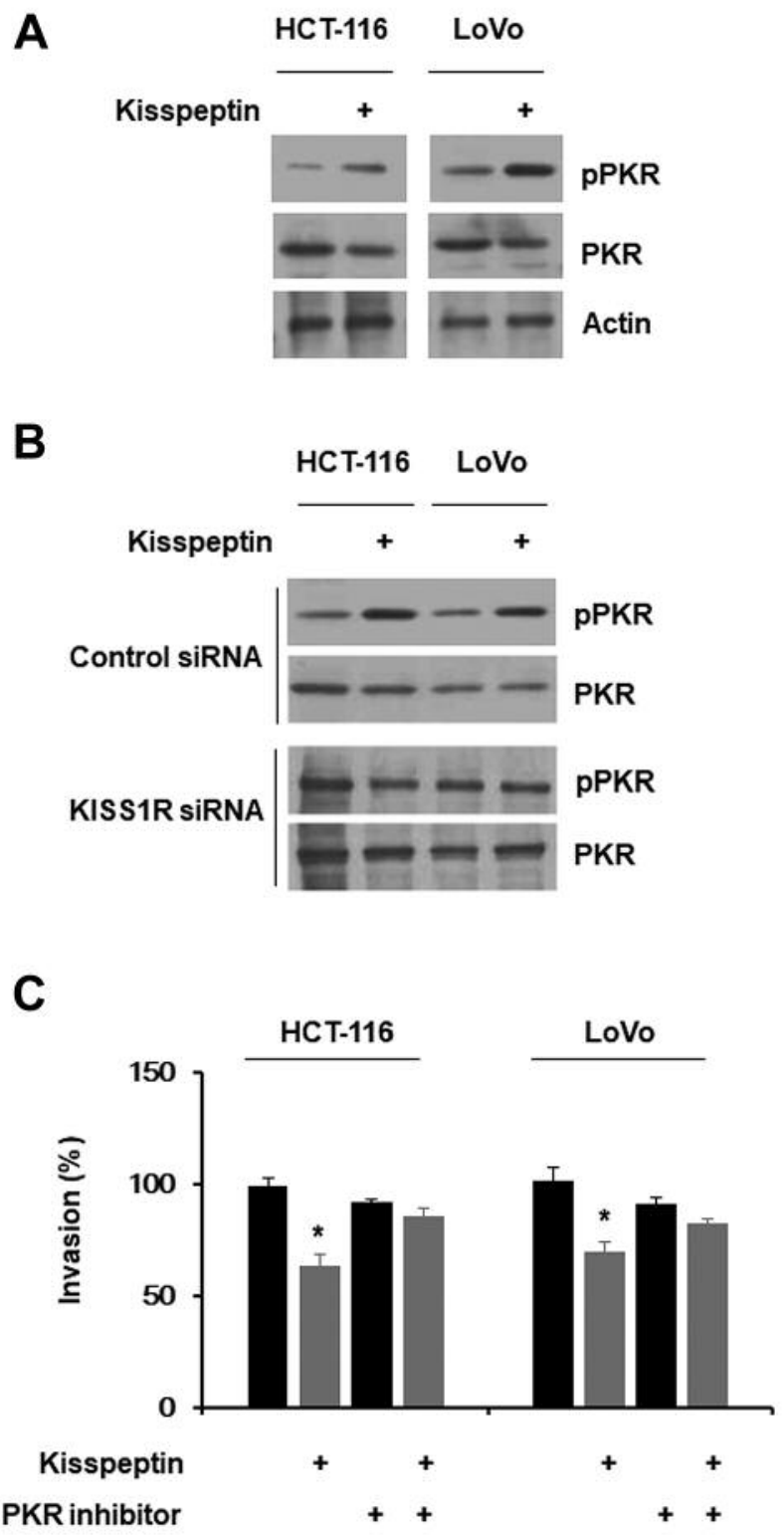

Figure 3. Kisspeptin inhibits colorectal cancer cell invasiveness via PKR phosphorylation. (A) Cells were treated with $100 \mathrm{nM}$ kisspeptin for 15 min and then cell extracts were subjected to western blots. (B) Cells were transfected with either control or KISSIR siRNA for $24 \mathrm{~h}$ and then treated with kisspeptin for $15 \mathrm{~min} .(C)$ Cells were pretreated with $200 \mathrm{nM}$ PKR inhibitor for $5 \mathrm{~min}$ and then treated with kisspeptin for another $12 h .{ }^{*} p<0.05$.

for $5 \mathrm{~min}$ and then treated with kisspeptin for $15 \mathrm{~min}$, PKR inhibition blocked PP2A phosphorylation, while PP2A inhibition did not affect PKR phosphorylation (Figure 4D). Therefore, our data indicate that kisspeptin repressed the invasiveness of colorectal cancer cells via PKR-PP2A signaling. 
A

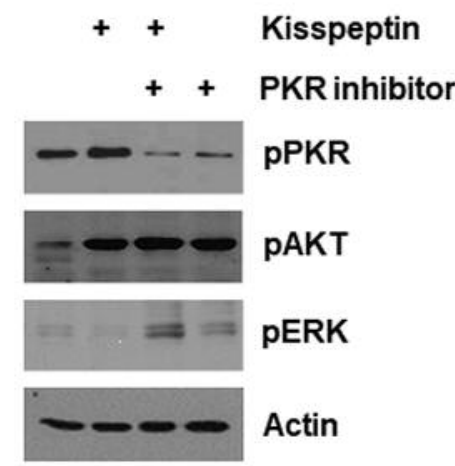

B

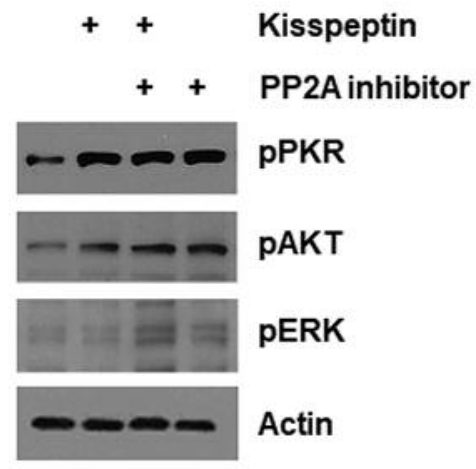

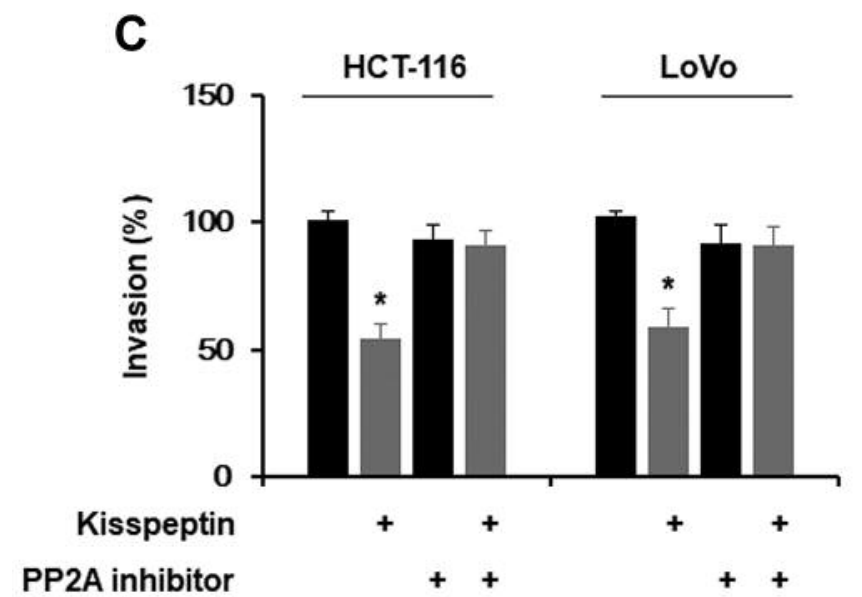

D
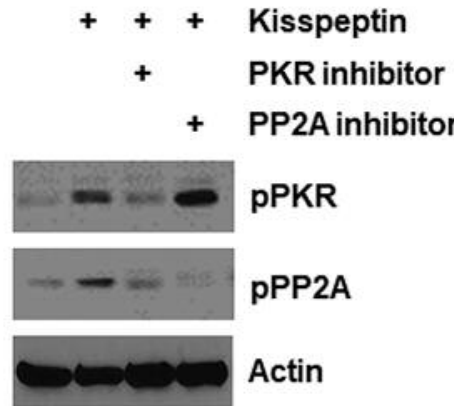

PP2A inhibitor

Figure 4. Kisspeptin-PKR signaling requires PP2A to inhibit colorectal cancer cell invasiveness. (A) Cells were pretreated with $200 \mathrm{nM} P$ PR inhibitor for $5 \mathrm{~min}$ and then treated with $100 \mathrm{nM}$ kisspeptin for another $15 \mathrm{~min}$. (B) Cells were pretreated with $3 \mu \mathrm{M}$ PP2A inhibitor for 5 min and then treated with kisspeptin at $100 \mathrm{nM}$ for another $15 \mathrm{~min} .(\mathrm{C})$ Cells were pretreated with $200 \mathrm{nM} P$ PR inhibitor for 5 min and then treated with $100 \mathrm{nM}$ kisspeptin for another $12 \mathrm{~h} .{ }^{*} p<0.05$. (D) Cells were pretreated with either $200 \mathrm{nM}$ PKR inhibitor or $3 \mu \mathrm{M}$ PP2A inhibitor for 5 min and then treated with $100 \mathrm{nM}$ kisspeptin for another $15 \mathrm{~min}$.

\section{Discussion}

Kisspeptin has been revealed to inhibit the invasiveness of colorectal cancer cells, while clinical data are controversial and required to be confirmed in depth $(10,19,20,23,29$ 34). Kisspeptin is known to reduce MMP-9 expression through either AKT or ERK in colorectal cancer $(10,19)$. These findings from different groups indicated an inhibitory role of kisspeptin against colorectal cancer cells. Moreover, our in vitro and in vivo studies revealed that kisspeptin blocked distant metastasis of LoVo colorectal cancer cells through PKR activation (23). In this study, kisspeptin signaling in the inhibition of colorectal cancer cell invasiveness was further investigated. Our data showed that kisspeptin repressed the invasiveness of colorectal cancer cells via PKR and PP2A.
In clinical data, KISS1 expression level was lower in colorectal cancer tissues than in adjacent normal tissues, and negatively correlated with poor prognosis, which is supported by KISS1 promoter methylation status in colorectal cancer tissues (20,31-33). However, other groups reported that KISS1 expression level was higher in colorectal cancer tissues than in adjacent normal tissues and that plasma kisspeptin level was also higher in colorectal cancer patients $(30,34)$. Kisspeptin treatment or KISS1 overexpression inhibited colorectal cancer cell migration and invasion by blocking MMP-9 expression, which was consistent with a negative correlation between KISS1 and MMP-9 expression levels in colorectal cancer patients (10, $19,20)$. Our present data consistently showed that kisspeptin treatment selectively blocks colorectal cancer cell migration and invasion. Kisspeptin inhibition of MMP-9 expression 
was achieved in part by inhibiting phosphorylation of either AKT or ERK. We have previously shown that kisspeptin inhibited pulmonary metastasis of LoVo colorectal cancer cells via PKR (23). Therefore, it is much plausible that kisspeptin represses the invasiveness of colorectal cancer cells. Higher kisspeptin levels in plasma samples of colorectal cancer patients or higher KISS1 expression levels in colorectal cancer tissues is likely to check colorectal cancer metastasis $(30,32)$. Therefore, colorectal cancer cells overcoming this kisspeptin-mediated metastasis checkpoint may metastasize to local tissues or distant organs. Kisspeptin regulation of epithelial-to-mesenchymal transition mechanism is one of putative mechanisms (35-37). Another possibility is that a role of kisspeptin signaling is dependent on different colorectal cancer types. Thus, we still require more research on the role of kisspeptin in colorectal cancer.

KISS1R requirement in kisspeptin-mediated inhibition of distant metastases is controversial. Welch and his colleagues showed that kisspeptin did not require KISS1R in melanoma metastases $(38,39)$. However, most studies reported kisspeptin repression via KISS1R (40-45). In colorectal cancer cells, our results showed that kisspeptin required KISS1R to inhibit the invasiveness. Meanwhile, we found that kisspeptin requires PKR and PP2A in the inhibition of colorectal cancer cell invasiveness. Our previous study revealed that kisspeptin regulated RhoA-PKR signaling (23). Here, we showed that the PKR inhibitor blocked kisspeptin-mediated phosphorylation of PKR but increased phosphorylation levels of both AKT and ERK. Thus, kisspeptin regulation of RhoA-PKR pathway is upstream of AKT and ERK. Moreover, kisspeptin activation of PKR inhibited phosphorylation of both AKT and ERK by increasing of PP2A activity. PKR regulation of PP2A has been revealed in various experimental sets $(24,25,46)$. In addition, PP2A inhibition of either AKT or ERK has been reported (24, 47). A recent study revealed that KISS1R interacts with PP2A in yeast two-hybrid and in vitro affinity purification assays (48). Nevertheless, it is unclear how kisspeptin signals to PKR and PP2A via KISS1R. PP2A inhibitor did not affect kisspeptinmediated PKR phosphorylation. Thus, kisspeptin signaling involves sequentially kisspeptin-KISS1R-RhoA-PKR-PP2A. Both PKR and PP2A are known as favorable prognosis markers in colorectal cancer patients $(28,49,50)$. Therefore, kisspeptin signaling may prevent colorectal cancer malignancy.

Kisspeptin is a well-known metastasis suppressor that can be tested in the repression of colorectal cancer metastasis. Our study reports that kisspeptin represses the invasiveness of colorectal cancer cells via KISS1R/PKR/PP2A. While more research is still required to decipher kisspeptin-mediated intracellular signaling in colorectal cancer cells, our ongoing work will focus on defining its role in different subtypes of colorectal cancer. Understanding kisspeptin's role in cancer will increase our understanding of the process of metastasis and may allow its clinical application.

\section{Conflicts of Interest}

The Authors declare that they have no conflict of interest.

\section{Acknowledgements}

This study was supported by Korea National University of Transportation in 2017 and by the Basic Science Research Program through National Research Foundation of Korea funded by the Ministry of Science, ICT and Future Planning (grant no. NRF2014R1A1A1035831).

\section{References}

1 Comninos AN and Dhillo WS: Emerging roles of kisspeptin in sexual and emotional brain processing. Neuroendocrinology 106(2): 195-202, 2018.

2 Liu $X$ and Herbison AE: Kisspeptin regulation of neuronal activity throughout the central nervous system. Endocrinol Metab (Seoul) 31(2): 193-205, 2016.

3 Lee JH and Welch DR: Suppression of metastasis in human breast carcinoma mda-mb-435 cells after transfection with the metastasis suppressor gene, kiss-1. Cancer Res 57(12): 23842387, 1997.

4 Lee JH, Miele ME, Hicks DJ, Phillips KK, Trent JM, Weissman BE and Welch DR: Kiss-1, a novel human malignant melanoma metastasis-suppressor gene. J Natl Cancer Inst 88(23): 17311737, 1996.

5 Lee DK, Nguyen T, O'Neill GP, Cheng R, Liu Y, Howard AD, Coulombe N, Tan CP, Tang-Nguyen AT, George SR and O'Dowd BF: Discovery of a receptor related to the galanin receptors. FEBS Lett 446(1): 103-107, 1999.

6 Ohtaki T, Shintani Y, Honda S, Matsumoto H, Hori A, Kanehashi K, Terao Y, Kumano S, Takatsu Y, Masuda Y, Ishibashi Y, Watanabe T, Asada M, Yamada T, Suenaga M, Kitada C, Usuki S, Kurokawa T, Onda H, Nishimura $\mathrm{O}$ and Fujino M: Metastasis suppressor gene kiss-1 encodes peptide ligand of a g-protein-coupled receptor. Nature 411(6837): 613617, 2001.

7 Muir AI, Chamberlain L, Elshourbagy NA, Michalovich D, Moore DJ, Calamari A, Szekeres PG, Sarau HM, Chambers JK, Murdock P, Steplewski K, Shabon U, Miller JE, Middleton SE, Darker JG, Larminie CG, Wilson S, Bergsma DJ, Emson P, Faull R, Philpott KL and Harrison DC: Axor12, a novel human $g$ protein-coupled receptor, activated by the peptide kiss-1. J Biol Chem 276(31): 28969-28975, 2001.

8 Kotani M, Detheux M, Vandenbogaerde A, Communi D, Vanderwinden JM, Le Poul E, Brezillon S, Tyldesley R, SuarezHuerta N, Vandeput F, Blanpain C, Schiffmann SN, Vassart G and Parmentier M: The metastasis suppressor gene kiss-1 encodes kisspeptins, the natural ligands of the orphan $g$ proteincoupled receptor gpr54. J Biol Chem 276(37): 34631-34636, 2001.

9 Jabeen S, Qureshi MZ, Javed Z, Iqbal MJ, Ismail M and Farooqi AA: Kisspeptin mediated signaling in cancer. Curr Top Med Chem 16(22): 2471-2476, 2016.

$10 \mathrm{Ji} \mathrm{K}$, Ye L, Ruge F, Hargest R, Mason MD and Jiang WG: Implication of metastasis suppressor gene, kiss-1 and its receptor kiss-1r in colorectal cancer. BMC Cancer 14: 723, 2014. 
11 Shin WJ, Cho YA, Kang KR, Kim JH, Hong SD, Lee JI, Hong SP and Yoon HJ: Kiss-1 expression in oral squamous cell carcinoma and its prognostic significance. APMIS 124(4): 291298, 2016.

12 Yuan TZ, Zhang HH, Tang QF, Zhang Q, Li J, Liang Y, Huang LJ, Zheng RH, Deng J and Zhang XP: Prognostic value of kisspeptin expression in nasopharyngeal carcinoma Laryngoscope 124(5): E167-174, 2014.

13 Nagai K, Doi R, Katagiri F, Ito T, Kida A, Koizumi M, Masui T, Kawaguchi Y, Tomita K, Oishi S, Fujii N and Uemoto S: Prognostic value of metastin expression in human pancreatic cancer. J Exp Clin Cancer Res 28: 9, 2009.

14 Pasquier J, Kamech N, Lafont AG, Vaudry H, Rousseau K and Dufour S: Molecular evolution of gpcrs: Kisspeptin/kisspeptin receptors. J Mol Endocrinol 52(3): T101-117, 2014.

15 Fang CY and Tseng M: Ethnic density and cancer: A review of the evidence. Cancer 124(9): 1877-1903, 2018.

16 Pellino G, Warren O, Mills S, Rasheed S, Tekkis PP and Kontovounisios C: Comparison of western and asian guidelines concerning the management of colon cancer. Dis Colon Rectum 61(2): 250-259, 2018.

17 Theodoratou E, Timofeeva M, Li X, Meng X and Ioannidis JPA: Nature, nurture, and cancer risks: Genetic and nutritional contributions to cancer. Annu Rev Nutr 37: 293-320, 2017.

18 Zellweger M, Abdelnour-Berchtold E, Krueger T, Ris HB, Perentes JY and Gonzalez M: Surgical treatment of pulmonary metastasis in colorectal cancer patients: Current practice and results. Crit Rev Oncol Hematol 127: 105-116, 2018.

19 Chen S, Chen W, Zhang X, Lin S and Chen Z: Overexpression of kiss-1 reduces colorectal cancer cell invasion by downregulating mmp-9 via blocking pi3k/akt/nf-kappab signal pathway. Int J Oncol 48(4): 1391-1398, 2016.

20 Zhu C, Takasu C, Morine Y, Bando Y, Ikemoto T, Saito Y, Yamada S, Imura S, Arakawa $\mathrm{Y}$ and Shimada M: Kiss1 associates with better outcome via inhibiting matrix metalloproteinase-9 in colorectal liver metastasis. Ann Surg Oncol 22(Suppl 3): S1516-1523, 2015.

21 Takino T, Koshikawa N, Miyamori H, Tanaka M, Sasaki T, Okada Y, Seiki M and Sato H: Cleavage of metastasis suppressor gene product kiss-1 protein/metastin by matrix metalloproteinases. Oncogene 22(30): 4617-4626, 2003.

22 Yan C, Wang H and Boyd DD: Kiss-1 represses 92-kda type iv collagenase expression by down-regulating nf-kappa $\mathrm{b}$ binding to the promoter as a consequence of ikappa balpha-induced block of p65/p50 nuclear translocation. J Biol Chem 276(2): 1164-1172, 2001.

$23 \mathrm{Kim}$ TH and Cho SG: Kisspeptin inhibits cancer growth and metastasis via activation of eif2ak2. Mol Med Rep 16(5): 75857590, 2017.

24 Blalock WL, Grimaldi C, Fala F, Follo M, Horn S, Basecke J, Martinelli G, Cocco L and Martelli AM: Pkr activity is required for acute leukemic cell maintenance and growth: A role for $\mathrm{pkr}$ mediated phosphatase activity to regulate gsk-3 phosphorylation. J Cell Physiol 221(1): 232-241, 2009.

$25 \mathrm{Xu} \mathrm{Z}$ and Williams BR: The b56alpha regulatory subunit of protein phosphatase $2 \mathrm{a}$ is a target for regulation by double-stranded rnadependent protein kinase pkr. Mol Cell Biol 20(14): 5285-5299, 2000.

26 Maggi LB Jr., Moran JM, Buller RM and Corbett JA: Erk activation is required for double-stranded rna- and virus-induced interleukin-1 expression by macrophages. J Biol Chem 278(19): 16683-16689, 2003.

27 Dai C, Zhang X, Xie D, Tang P, Li C, Zuo Y, Jiang B and Xue C: Targeting pp2a activates ampk signaling to inhibit colorectal cancer cells. Oncotarget 8(56): 95810-95823, 2017.

28 Wang SS, Esplin ED, Li JL, Huang L, Gazdar A, Minna J and Evans GA: Alterations of the ppp2r1b gene in human lung and colon cancer. Science 282(5387): 284-287, 1998.

29 Mousavi Ardehaie R, Hashemzadeh S, Behrouz Sharif S, Ghojazadeh M, Teimoori-Toolabi L and Sakhinia E: Aberrant methylated ednrb can act as a potential diagnostic biomarker in sporadic colorectal cancer while kiss1 is controversial. Bioengineered 8(5): 555-564, 2017.

30 Kostakis ID, Agrogiannis G, Vaiopoulos AG, Mylona E, Patsouris E, Kouraklis G and Koutsilieris M: A clinicopathological analysis of kiss1 and kiss1r expression in colorectal cancer. APMIS 123(7): 629-637, 2015.

31 Chen SQ, Chen ZH, Lin SY, Dai QB, Fu LX and Chen RQ: Kiss 1 methylation and expression as predictors of disease progression in colorectal cancer patients. World J Gastroenterol 20(29): 10071-10081, 2014.

32 Kostakis ID, Agrogiannis G, Vaiopoulos AG, Mylona E, Patsouris E, Kouraklis G and Koutsilieris M: Kiss 1 expression in colorectal cancer. APMIS 121(10): 1004-1010, 2013.

33 Okugawa Y, Inoue Y, Tanaka K, Toiyama Y, Shimura T, Okigami M, Kawamoto A, Hiro J, Saigusa S, Mohri Y, Uchida $\mathrm{K}$ and Kusunoki M: Loss of the metastasis suppressor gene kiss1 is associated with lymph node metastasis and poor prognosis in human colorectal cancer. Oncol Rep 30(3): 14491454, 2013.

34 Canbay E, Ergen A, Bugra D, Yamaner S, Eraltan IY, Buyukuncu $\mathrm{Y}$ and Bulut T: Kisspeptin-54 levels are increased in patients with colorectal cancer. World J Surg 36(9): 2218-2224, 2012.

35 Tan K, Cho SG, Luo W, Yi T, Wu X, Siwko S, Liu M and Yuan W: Kiss1-induced gpr54 signaling inhibits breast cancer cell migration and epithelial-mesenchymal transition via protein kinase d1. Curr Mol Med 14(5): 652-662, 2014.

36 Teng Y, Mei Y, Hawthorn L and Cowell JK: Wasf3 regulates mir-200 inactivation by zeb1 through suppression of kiss1 leading to increased invasiveness in breast cancer cells. Oncogene 33(2): 203-211, 2014

37 Song GQ and Zhao Y: Kisspeptin-10 inhibits the migration of breast cancer cells by regulating epithelial-mesenchymal transition. Oncol Rep 33(2): 669-674, 2015.

38 Nash KT, Phadke PA, Navenot JM, Hurst DR, Accavitti-Loper MA, Sztul E, Vaidya KS, Frost AR, Kappes JC, Peiper SC and Welch DR: Requirement of kiss 1 secretion for multiple organ metastasis suppression and maintenance of tumor dormancy. J Natl Cancer Inst 99(4): 309-321, 2007.

39 Yang Y, Gao J, Yuan C, Zhang Y, Guan Y and Wang Z: Molecular identification of kiss/gpr54 and function analysis with mrna expression profiles exposure to 17alpha-ethinylestradiol in rare minnow gobiocypris rarus. Mol Biol Rep 43(7): 737-749, 2016.

40 Ziegler E, Olbrich T, Emons G and Grundker C: Antiproliferative effects of kisspeptin10 depend on artificial gpr54 (kiss1r) expression levels. Oncol Rep 29(2): 549-554, 2013.

41 Roseweir AK, Katz AA and Millar RP: Kisspeptin-10 inhibits cell migration in vitro via a receptor-gsk 3 beta-fak feedback loop in htr8svneo cells. Placenta 33(5): 408-415, 2012. 
42 Olbrich T, Ziegler E, Turk G, Schubert A, Emons G and Grundker C: Kisspeptin-10 inhibits bone-directed migration of gpr54-positive breast cancer cells: Evidence for a dose-window effect. Gynecol Oncol 119(3): 571-578, 2010.

43 Shoji S, Tang XY, Umemura S, Itoh J, Takekoshi S, Shima M, Usui Y, Nagata Y, Uchida T, Osamura RY and Terachi T: Metastin inhibits migration and invasion of renal cell carcinoma with overexpression of metastin receptor. Eur Urol 55(2): 441449, 2009.

44 Uno M, Kokuryo T, Yokoyama $\mathrm{Y}$, Senga $\mathrm{T}$ and Nagino $\mathrm{M}$ : Alpha-bisabolol inhibits invasiveness and motility in pancreatic cancer through kiss1r activation. Anticancer Res 36(2): 583-589, 2016.

45 Savvidis C, Papaoiconomou E, Petraki C, Msaouel P and Koutsilieris M: The role of kiss1/kiss1r system in tumor growth and invasion of differentiated thyroid cancer. Anticancer Res 35(2): 819-826, 2015.

46 Cheng X, Bennett RL, Liu X, Byrne M and Stratford May W: $\mathrm{Pkr}$ negatively regulates leukemia progression in association with pp2a activation, bcl-2 inhibition and increased apoptosis. Blood Cancer J 3: e144, 2013.

47 Watt LF, Panicker N, Mannan A, Copeland B, Kahl RGS, Dun MD, Young B, Roselli S and Verrills NM: Functional importance of pp2a regulatory subunit loss in breast cancer. Breast Cancer Res Treat 166(1): 117-131, 2017.
48 Evans BJ, Wang Z, Mobley L, Khosravi D, Fujii N, Navenot JM and Peiper SC: Physical association of gpr54 c-terminal with protein phosphatase 2a. Biochem Biophys Res Commun 377(4): 1067-1071, 2008.

49 Cristobal I, Carames C, Rincon R, Manso R, Madoz-Gurpide J, Torrejon B, Gonzalez-Alonso P, Rojo F and Garcia-Foncillas J: Downregulation of microrna-199b predicts unfavorable prognosis and emerges as a novel therapeutic target which contributes to $\mathrm{pp} 2 \mathrm{a}$ inhibition in metastatic colorectal cancer. Oncotarget 8(25): 40169-40180, 2017.

50 Kwon HC, Moon CH, Kim SH, Choi HJ, Lee HS, Roh MS, Hwang TH, Kim JS and Kim HJ: Expression of double-stranded rna-activated protein kinase $(\mathrm{pkr})$ and its prognostic significance in lymph node negative rectal cancer. Jpn J Clin Oncol 35(9): 545-550, 2005.
Received August 7, 2018

Revised August 21, 2018

Accepted August 27, 2018 